\title{
Irrigation Timing Impacts the Efficacy of Foliar-Applied Fungicides Toward Foliar and Soilborne Pathogens of Peanut
}

J. E. Woodward, Extension Plant Pathologist, Texas AgriLife Extension Service, Lubbock, TX 79403-6603 and Associate Professor, Department of Plant and Soil Science, Texas Tech University, Lubbock 79409-2122; and T. B. Brenneman, Professor, Department of Plant Pathology, and B. G. Mullinix, Jr., Research Statistician (Retired), Experimental Statistics Unit, The University of Georgia, Coastal Plain Experiment Station, Tifton 31793-0748

\begin{abstract}
Woodward, J. E., Brenneman, T. B., and Mullinix, B. G., Jr. 2012. Irrigation timing impacts the efficacy of foliar-applied fungicides toward foliar and soilborne pathogens of peanut. Plant Dis. 96:1785-1790.

Fungicides not reaching target organisms result in decreased disease control. In the southeastern United States, foliar-applied fungicides are routinely used to manage peanut (Arachis hypogaea) diseases. Irrigation is often applied to wash fungicides from treated foliage to obtain maximum control of diseases caused by soilborne pathogens. Administering irrigation before fungicide residues have dried may adversely impact foliar disease control. A microplot study was conducted in 2003, 2004, and 2005 to evaluate the redistribution of azoxystrobin, tebuconazole, and flutolanil plus chlorothalonil following different irrigation timings. Standard fungicide regimes were subjected to 1.3$\mathrm{cm}$ of irrigation $0,6,12,24,48$, or $96 \mathrm{~h}$ after application, and a nonirrigated control was included. Microplots not receiving irrigation were covered while irrigation treatments were administered. Irrigation timing was significant for the number of early leaf spot (Cercospora arachidicola) lesions per leaf. Leaf spot was more severe when irriga-

tion was administered immediately following fungicide applications, and was significantly reduced with a 6- and 12-h delay prior to an irrigation event, whereas maximum control was obtained when irrigation was delayed for $24 \mathrm{~h}$ or later. To further quantify fungicide residue distribution, Sclerotium rolfsii was used to bioassay foliage and pods. Lesion development on leaflets, which was greater for earlier irrigation timings, did not differ for the 12-h and later timings and was generally similar to the nonirrigated controls. Pod colonization for all fungicides increased according to a quadratic function of irrigation timing, with the least colonization occurring at the 0 -h timing. Colonization of pods treated with azoxystrobin was similar for all irrigation timings; whereas, suppression was greatest for tebuconazole at earlier irrigation timings. This study demonstrates that irrigation can be used to redistribute fungicides applied to peanut foliage to improve control of soilborne pathogens but administering irrigation within $24 \mathrm{~h}$ may decrease leaf spot control.
\end{abstract}

Multiple applications of fungicides are required to properly control fungal pathogens of peanut (Arachis hypogaea L.). In the southeastern United States, standard fungicide programs are initiated approximately 30 days after planting (DAP) and subsequent applications are made at 14-day intervals, resulting in seven or more applications per season $(32,33)$. The most important foliar diseases are early leaf spot, caused by Cercospora arachidicola Hori, and late leaf spot, caused by Cercosporidium personatum (Berk. \& M.A. Curtis) Deighton, whereas stem rot (caused by Sclerotium rolfsii Sacc.) is the most damaging soilborne disease (31).

Various management options are available to producers for leaf spot control. Prior to the 1970s, copper fungicides were commonly used for suppression of leaf spot; however, the registration of chlorothalonil revolutionized leaf spot management for producers (43). Chlorothalonil is still effective against leaf spot; however, additional compounds are required for the management of stem rot $(20,25)$. In the past, stem rot suppression was achieved through applications of pentachloronitrobenzene (17) and, to a lesser extent, the insecticide chlorpyrifos $(14,26)$. Because $S$. rolfsii initially infects near the base of main stems of plants $(2,39)$, these products were formulated as granules and banded over the peanut row center (17). Granules were thought to be needed to penetrate the foliage, but control using these materials was costly and inconsistent $(15,17)$.

More recently, registration of the benzanilide fungicide flutolanil has provided producers with a more effective means of managing stem rot $(16,25)$; however, flutolanil is not active against leaf spot

Corresponding author: J. E. Woodward, E-mail: jewoodward@ag.tamu.edu

Accepted for publication 2 July 2012.

http://dx.doi.org/10.1094/PDIS-01-12-0042-RE

(C) 2012 The American Phytopathological Society and must be tank mixed with chlorothalonil or propiconazole to obtain control of this disease (21). Furthermore, the registration of ergosterol biosynthesis-inhibiting (EBI) fungicides and strobilurin (QoI) fungicides, such as tebuconazole and azoxystrobin, respectively, has greatly improved both stem rot and leaf spot management over the past decade $(7-9,24,25)$. In contrast to granular fungicides, broadcast-spray applications of these compounds are made to peanut foliage. Fungicide deposition within the canopy contributes to efficacy for leaf spot, but the management of stem rot is more difficult, because the deposition target for stem rot control is at the base of the plant as well as belowground pegs and pods. The mechanism by which foliar-applied fungicides affect stem rot is not fully understood. It is believed that initial deposits of fungicides within the upper canopy are washed onto stems and pegs at the base of the plant via dew, rainfall, or irrigation (45). This hypothesis was tested by Csinos and Kvien (18), by using methyl-blue dye to demonstrate fungicide redistribution into the soil around the pegs and pods with irrigation.

As a result of these studies and observations of sporadic reductions in efficacy of foliar-applied fungicides in nonirrigated fields, producers in Georgia are advised to irrigate following fungicide applications in order to maximize stem rot control (33). Irrigating too quickly may compromise leaf spot control, but the timings needed to optimize control of both soilborne disease and leaf spot are not well documented. The purpose of this study was to evaluate the redistribution of several fungicides commonly used to manage peanut diseases in the southeastern United States following different irrigation timings. Specific objectives were to (i) evaluate the effects of irrigation timing relative to spraying on fungicide efficacy for leaf spot, (ii) compare the distribution of fungicides on peanut foliage and pods under different irrigation timings, and (iii) determine the optimum irrigation timing needed for maximum suppression of foliar and soilborne pathogens with each product evaluated 


\section{Materials and Methods}

Field experiments. Microplot studies were conducted at the University of Georgia-Coastal Plain Experiment Station Black Shank Farm located in Tifton, GA in 2003, 2004, and 2005. Microplots were constructed out of cylindrical aluminum rings $(0.9 \mathrm{~m}$ in diameter by $0.3 \mathrm{~m}$ high) and buried $15 \mathrm{~cm}$ deep in the soil. The soil type for the plot area was a Fuquay sand (loamy, kaolinitic, thermic Arenic Plinthic Kandiult, $\mathrm{pH}=6.1$ ). Microplots were tilled by hand and fumigated with metam sodium (Vapam 32\%; AMVAC Chemical Corp.) at 1,429 liters ha ${ }^{-1} 3$ to 4 weeks prior to planting. In total, nine Georgia Green peanut seeds were hand planted in a triangular pattern in each plot on 25 Jun 2003, 14 May 2004, and 10 June 2005. After emergence, plant populations were thinned to three plants per microplot. Fungicide applications were initiated 21 DAP, and applied on a 14-day schedule to complete a seven-spray regime. Fungicide programs evaluated are those typically used by growers and included (i) seven applications of chlorothalonil

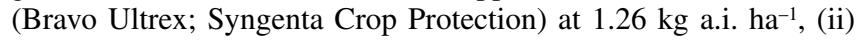
four sequential applications of tebuconazole (Folicur 3.6F; Bayer Crop Protection) at $0.23 \mathrm{~kg}$ a.i. $\mathrm{ha}^{-1}$ preceded by three chlorothalonil applications, (iii) two applications of azoxystrobin (Abound 2.08F; Syngenta Crop Protection) at $0.47 \mathrm{~kg}$ a.i. ha ${ }^{-1}$ applied 63 and 91 DAP, and (iv) two flutolanil (Moncut 70DF; Gowan, Co.) at $1.0 \mathrm{~kg}$ a.i. ha $\mathrm{h}^{-1}$ plus chlorothalonil at $1.26 \mathrm{~kg}$ a.i. ha $\mathrm{h}^{-1}$ plus applications made 63 and 91 DAP. For the azoxystrobin and flutolanil plus chlorothalonil programs, additional applications of chlorothalonil were made to complete a seven-spray regime. A detailed description of the fungicide programs evaluated can be found in Table 1.

Irrigation $(1.3 \mathrm{~cm})$ was administered $0,6,12,24,48$, or $96 \mathrm{~h}$ after the application of fungicides for applications 4 through 7 via solid set sprinklers. Nonirrigated microplots served as controls. Plywood sheets (1.2 by $1.2 \mathrm{~m}$ ) were used to cover microplots not scheduled to receive irrigation or to exclude rainfall during the first $96 \mathrm{~h}$ after each application. Rain outside this time period was allowed to fall on all plots. All microplots were irrigated $(0.7 \mathrm{~cm})$ and allowed to dry prior to the application of fungicides to minimize the effects of additional water. Irrigation treatments were randomly assigned to each fungicide program, except the chlorothalonil program, which only received irrigation at the $24-\mathrm{h}$ timing.

The experiment consisted of a three-by-seven factorial plus one chlorothalonil standard, resulting in a total of 22 treatments, which were arranged in a randomized complete block design with seven replications. All production practices other than disease control and irrigation were based on conventional management practices specified by the University of Georgia Cooperative Extension Service (6).

Bioassay procedures. Main stems were collected at 68,96 , and 110 DAP from plants in each microplot $24 \mathrm{~h}$ after the final irrigation treatment had been administered. Stems were excised from the host plant crown, placed in plastic freezer bags, and transported to the laboratory. Leaflets were taken from the upper, middle, and lower third of each plant canopy, placed in petri dishes containing moistened filter paper, and inoculated with $S$. rolfsii using the methods described by Woodward and Brenneman (48). Petri dishes were transferred to a growth chamber that was maintained at $28^{\circ} \mathrm{C}$ and $95 \%$ relative humidity in the dark. After 3 days of incubation, lesion area (in square centimeters) was recorded for excised leaflets.

The same sampled leaves also expressed symptoms of leaf spot, which originated from natural inoculum. Leaf spot was evaluated by counting the numbers of lesions per leaf within each canopy layer prior to inoculating with $S$. rolfsii at the 110-DAP sampling date. A similar inoculation method, with $S$. rolfsii, was developed to assay peanut pods. Following the removal of main stems, peanut plants were excavated by hand and three pods closest to the tap root were arbitrarily collected and taken to the laboratory. Excised pods were placed in petri dishes containing moistened, sterile filter paper. Pods were inoculated with 0.5 -cm-diameter potato dextrose agar plugs obtained from the growing margin of 3-day-old S. rolfsii cultures. Agar plugs were placed mycelium side down on the dorsal side of the pod, below the point of peg attachment. Petri dishes were covered, placed in a growth chamber, and maintained as described previously. Disease assessments, visually estimated as the percentage of the pod colonized by $S$. rolfsii, were taken 72 and $120 \mathrm{~h}$ after inoculation.

Statistical analysis. Data were analyzed using Proc MIXED of SAS (SAS Institute Inc.) and the experimental design consisted of 3 years, seven replications, four fungicide programs, seven irrigation treatments, and three plant positions during the growing season arranged in a split-split plot for each sampling date. Two models were used for data analysis because the chlorothalonil program only received irrigation at the $24-\mathrm{h}$ timing. The first analysis included all four fungicides for the purpose of determining the size of the error in the data collected. The second analysis excluded the chlorothalonil program. Fixed effects examined included main effects and all interactions among fungicide, irrigation, and position. Random effects included year, rep(year), year-fungicide, year-irrigation, year-fungicide-irrigation, rep-fungicide-irrigation(year), rep-position, year-fungicide-position, year-irrigationposition, and year-fungicide-irrigation-position. In the model statement, the option for determining the appropriate degrees of freedom (ddfm) method was Satterthwaite (ddfm = satterth). Reductions of the full model were made for each variable until the condition that all interactions remaining were significant at the $P=$ 0.05 level (the three main effect variables always remained in the model). LSMEANS were obtained with the appropriate standard error of the mean and the Satterthwaite corrected df for each pair of means using the PDIFF option. Least significant difference values were calculated using the standard errors and $t$ values representing the adjusted degrees of freedom from the pairwise comparison of means from the analysis. For use in regression analysis, the intercept was transferred to the mean irrigation timing as suggested by Draper and Smith (23). The response of $S$. rolfsii growth on pods, reported as the percent colonization, to the different irrigation timings was evaluated by nonlinear regression for fit to a quadratic equation, percent $=a+b x+c x^{2}$, where $a=$ the intercept, $b=$ the instantaneous slope at the mean of $x, c=$ rate of change in either direction of the mean of $x$, and $x=$ irrigation timing minus the mean of irrigation timing (42). The significance of a nonlinear fit was determined if the $95 \%$ confidence interval did not include

Table 1. Description of fungicide programs used to evaluate the effect of irrigation on the redistribution of fungicides applied to peanut foliage

\begin{tabular}{llcclll}
\hline Program, active ingredients & Trade name & Formulation $^{\mathbf{a}}$ & ${\text { Rate }\left(\mathbf{k g ~ h a}^{-1}\right)}^{\text {Application }}$ & & Chemical class & Systemicity \\
\hline (i) Chlorothalonil & Bravo Ultrex & $82.5 \mathrm{WDG}$ & 1.26 & $1-7$ & Broad-spectrum protectant & None \\
(ii) Chlorothalonil & Bravo Ultrex & $82.5 \mathrm{WDG}$ & 1.26 & $1,2,3,5,7$ & Broad-spectrum protectant & None \\
Azoxystrobin & Abound & $2.08 \mathrm{~F}$ & 0.47 & 4,6 & Strobilurin & Acropetal \\
(iii) Chlorothalonil & Bravo Ultrex & $82.5 \mathrm{WDG}$ & 1.26 & $1-3$ & Broad-spectrum protectant & None \\
Tebuconazole & Folicur & $3.6 \mathrm{~F}$ & 0.33 & $4-7$ & Sterol biosynthesis inhibitor & Acropetal \\
(iv) Chlorothalonil & Bravo Ultrex & $82.5 \mathrm{WDG}$ & 1.26 & $1,2,3,5,7$ & Broad-spectrum protectant & None \\
Chlorothalonil + flutolanil & Moncut & $70 \mathrm{DF}$ & 1.00 & 4,6 & Benzanilide & Acropetal \\
\hline
\end{tabular}

${ }^{a}$ Percentages of active ingredients in commercial products formulated as water dispersible granules (WDG), flowable, or dry flowable (DF).

${ }^{\mathrm{b}}$ When applications were made to complete a seven-spray program.

${ }^{\mathrm{c}}$ Fungicide movement in the plant: none (no systemic movement) or acropetal (upward movement through the xylem). 
zero. Proc TTEST (SAS Institute Inc.) was used to test for differences among the results from the nonlinear regression between the chlorothalonil standard, and the nonirrigated controls. The chlorothalonil standard was compared with the fungicide intercepts and the nonirrigated treatments.

\section{Results}

Bioassay of leaflets. Fungicide effects were significant on the development of $S$. rolfsii lesions on leaflets for the 68- and 110DAP sampling dates but not 82 DAP (data not shown). As would be expected, the application of tebuconazole, azoxystrobin, or flutolanil plus chlorothalonil significantly reduced lesion area on leaflets similarly, compared with those treated with chlorothalonil (data not shown). A significant irrigation-canopy layer interaction was present for lesion development on leaflets for all three sampling dates; therefore, data are presented accordingly (Table 2). Lesion development was much greater with early (0- to 12-h) irrigation timings that would have removed fungicides from the leaves. Later irrigation timings did not differ from the nonirrigated control. Significant differences in lesion development were also observed among canopy layers, but only when irrigation was applied at $0 \mathrm{~h}$ (Table 2). At all sampling dates, there was more colonization at $0 \mathrm{~h}$ in the upper versus lower canopy levels.

Leaf spot. Only irrigation effects were found to be significant for the leaf spot data. Due to a lack of any interactions, data were pooled across fungicide and canopy layer. Overall, longer delays between spraying fungicides and applying irrigation resulted in greater suppression of leaf spot (Fig. 1). There were significantly more lesions per leaf for the 0-h irrigation treatment compared with all other treatments. Allowing fungicides to remain on the leaf surface for $6 \mathrm{~h}$ reduced the number of lesions per leaf, and a further reduction was observed for the 12 -h irrigation timing. The number of leaf spot lesions did not differ from the nonirrigated control or the chlorothalonil standard for irrigation timings of $24 \mathrm{~h}$ or greater.

Bioassay of pods. For the pod assay, only irrigation effects were significant. The regressions of percent pod colonization over time and appropriate controls are illustrated in Figure 2. Although the fungicide-irrigation interaction was not significant, analysis revealed differences in the rate of change among fungicides (data not shown). The three lines were fitted to a second-order polynomial across irrigation timing, and the two parameters showed no significant differences among the three fungicides (Fig. 2). When compared with the respective controls, the intercepts where not signifi- cant for azoxystrobin $(t=1.81$, df $=93, P=0.05)$, but highly significant for tebuconazole $(t=5.99$, df $=93, P=0.01)$ and flutolanil plus chlorothalonil $(t=2.86$, $\mathrm{df}=93, P=0.01)$. The nonirrigated tebuconazole control differed significantly from the chlorothalonil standard $(t=7.15$, df $=93, P=0.01)$, as did the azoxystrobin $(t=8.20$, df $=93, P=0.01)$ and flutolanil plus chlorothalonil $(t=9.10, \mathrm{df}=93, P=0.01)$ nonirrigated controls. Overall, pod colonization increased as irrigation timing was delayed (Fig. 2). With 12.0, 17.3, 22.0, and 29.5\% for the 0-, 6-, 12-, and 24-h irrigation timings, respectively, tebuconazole proved extremely sensitive to irrigation (Fig. 2A). Similar trends were observed for azoxystrobin and flutolanil plus chlorothalonil; however, suppression of $S$. rolfsii pod colonization was not as great for those fungicides as for tebuconazole during the first $24 \mathrm{~h}$. Pod colonization was 19.7 to $44.3 \%$ and 19.7 to $40.7 \%$ for the 0 - to 24 $\mathrm{h}$ irrigation timings for azoxystrobin (Fig. 2B) and flutolanil plus chlorothalonil (Fig. 2C), respectively.

\section{Discussion}

Limited information is currently available regarding the redistribution of fungicides from rainfall or irrigation. Most of what has been reported pertains to the influence of rainfall and the rainfastness of protectant compounds $(12,35,38,44)$. Information regarding mechanisms of suppressing soilborne pathogens with foliar-applied fungicides is even more limited. Cooke et al. (13) documented that simulated rainfall increased suppression of eyespot of wheat, caused by Pseucocercosporella herpotrichoides, for prochloraz. They hypothesized that initial foliar fungicide deposits are washed to the base of the plant by rainfall or dew, thus improving contact with soilborne pathogens, which resulted in enhanced disease control. A similar phenomenon has been reported in peanut. Csinos and Kvien (18) demonstrated that irrigation was an effective means of redistributing foliar-applied dyes to peanut crowns and pegs. Subsequent studies found that an increase in stem rot suppression was achieved in fungicide evaluations, with the redistribution of fungicide residues from the foliage to $S$. rolfsii infection sites on stems, pegs, and pods $(3,36)$. Using $S$. rolfsii to bioassay peanut tissues, we were able to quantify the redistribution of foliar-applied fungicides using irrigation and to examine the effects of different irrigation timings.

Chemical analyses were not conducted in this study; however, previous reports have indicated that bioassays are an effective means of assessing the biological activity of fungicides $(10,40,47)$

Table 2. Effects of irrigation timing applied after foliar applications of azoxystrobin, flutolanil, and tebuconazole on the development of Sclerotium rolfsii lesions on detached peanut leaflets obtained from three canopy layers on three sampling dates of field-grown peanut plants ${ }^{\mathrm{a}}$

\begin{tabular}{|c|c|c|c|c|c|c|c|}
\hline \multirow[b]{2}{*}{ Date, layer ${ }^{b}$} & \multicolumn{7}{|c|}{ Lesions $\left(\mathrm{mm}^{2}\right)$ per irrigation timing } \\
\hline & $\mathbf{O h}$ & $6 \mathrm{~h}$ & $12 \mathrm{~h}$ & $24 \mathrm{~h}$ & $48 \mathrm{~h}$ & $96 \mathrm{~h}$ & None \\
\hline \multicolumn{8}{|l|}{68 DAP } \\
\hline Upper & 218.7 & 58.8 & 28.0 & 35.1 & 25.3 & 15.4 & 12.3 \\
\hline Middle & 131.6 & 50.9 & 33.1 & 34.1 & 25.9 & 21.4 & 20.3 \\
\hline Lower & 109.9 & 72.5 & 37.9 & 62.7 & 40.3 & 27.9 & 35.6 \\
\hline $\mathrm{LSD}^{\mathrm{c}}$ & $\ldots$ & $\ldots$ & $\ldots$ & 30.4 & $\ldots$ & $\ldots$ & $\ldots$ \\
\hline $\mathrm{LSD}^{\mathrm{d}}$ & $\ldots$ & $\ldots$ & $\ldots$ & 28.6 & $\ldots$ & $\ldots$ & $\ldots$ \\
\hline \multicolumn{8}{|l|}{82 DAP } \\
\hline Upper & 175.4 & 81.1 & 45.7 & 17.6 & 24.1 & 28.9 & 15.6 \\
\hline Middle & 106.5 & 69.0 & 55.0 & 44.9 & 53.3 & 30.4 & 20.2 \\
\hline Lower & 71.4 & 49.2 & 59.0 & 32.8 & 34.1 & 25.9 & 26.6 \\
\hline $\mathrm{LSD}^{\mathrm{c}}$ & $\ldots$ & $\ldots$ & $\ldots$ & 26.9 & $\ldots$ & $\ldots$ & $\ldots$ \\
\hline LSD $^{\mathrm{d}}$ & $\ldots$ & $\ldots$ & $\ldots$ & 31.0 & $\ldots$ & $\ldots$ & $\ldots$ \\
\hline \multicolumn{8}{|l|}{110 DAP } \\
\hline Upper & 381.0 & 104.6 & 56.0 & 25.1 & 16.8 & 8.8 & 8.0 \\
\hline Middle & 254.0 & 83.9 & 66.5 & 36.3 & 43.0 & 32.0 & 11.3 \\
\hline Lower & 173.0 & 74.5 & 68.3 & 51.2 & 46.2 & 35.6 & 32.0 \\
\hline $\mathrm{LSD}^{\mathrm{c}}$ & $\ldots$ & $\ldots$ & $\ldots$ & 57.9 & $\ldots$ & $\ldots$ & $\ldots$ \\
\hline $\mathrm{LSD}^{\mathrm{d}}$ & $\ldots$ & $\ldots$ & $\ldots$ & 81.4 & $\ldots$ & $\ldots$ & $\ldots$ \\
\hline
\end{tabular}

\footnotetext{
${ }^{\text {a }}$ Data are the means of 21 replications from 2003, 2004, and 2005.

${ }^{\mathrm{b}}$ Sampling date in days after planting (DAP) and canopy layer.

${ }^{\mathrm{c}}$ LSD to compare canopy layers within irrigation timings $(P=0.05)$.
}

${ }^{\mathrm{d}}$ LSD to compare irrigation timings within canopy layers $(P=0.05)$ 
In this study, $S$. rolfsii lesion development was greatest on peanut leaflets collected from microplots receiving irrigation immediately following the application of fungicides. This was apparently due to the removal of fungicide residues from those tissues, which were then deposited on the lower plant parts or soil. The earliest irrigation timing provided maximum fungicide redistribution and, therefore, suppression of $S$. rolfsii colonization of the pods.

Several factors are known to affect fungicide deposition, including differences in leaf structure, primarily the cuticle $(37,38)$, which can be altered by different environmental factors (41). These studies were conducted using field-grown plants to mimic the retention of initial fungicide deposits on foliage under field conditions. Pesticide deposition is also greatly affected by canopy density. Higher levels of chlorothalonil are deposited on the upper plant canopy compared with the lower canopy $(11,27)$. Zhu et al. (49), found that spray deposits in the upper and lower peanut canopy differed significantly, and that deposits in the lower canopy decreased as plants aged and got bigger. Differences in the initial deposit of fungicides could not be determined in this study, due to varying levels of tissue susceptibility from the different canopy layers (48). Lesion development was generally smallest on tissues from the lower canopy, followed by the middle and upper canopy, respectively. This trend was most apparent when microplots were irrigated immediately after fungicides were applied; however, it became less obvious for later irrigation timings, as well as the nonirrigated controls.

Lesion development was not compared among the three sampling dates; however, lesion size on leaflets was numerically higher for the 110-DAP sampling date. This phenomenon may also impact the control of diseases caused by soilborne pathogens. S. rolfsii growth and the development of stem rot is favored by the hot, moist environmental conditions within the peanut canopy (2). The biomass of the plant increases with age, and a thicker canopy would intercept foliar-applied fungicides. These two factors indicate the importance of redistributing fungicides with irrigation to the lower stems and pods where $S$. rolfsii infections occur, especially later in the season.

Canopy layer effects were not significant for leaf spot in this study, and differences in tissue susceptibility within the peanut canopy were not explored. However, leaf spot is typically more severe in the lower canopy early in the season prior to infecting other parts of the canopy (36). Failure to see this trend is likely due to the fact that a fumigant was used prior to planting. Use of the fumigant may have reduced initial inoculum in the soil; thus, infec-

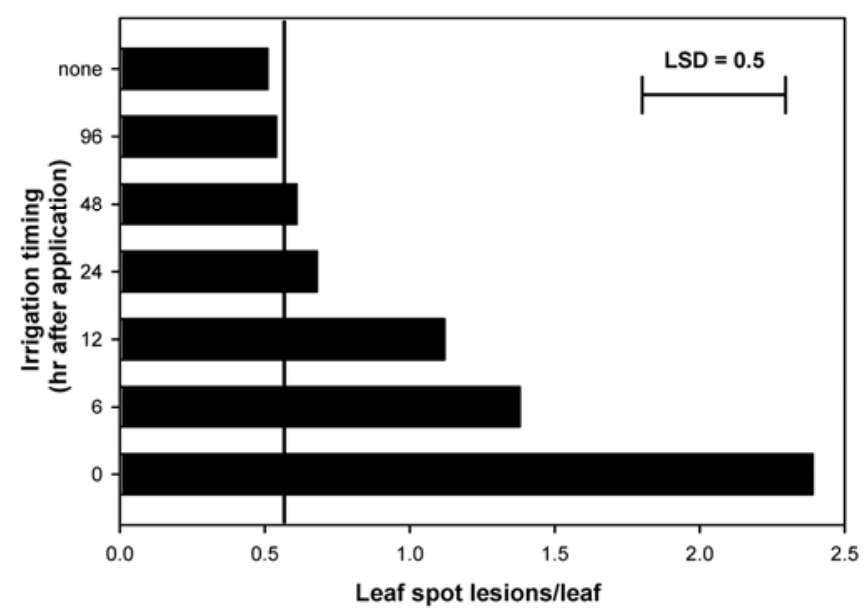

Fig. 1. Effect of irrigation timing on the development of leaf spot lesions of peanut. Bars are the means of 21 replications from 2003, 2004, and 2005, pooled across three canopy layers, as well as the azoxystrobin, chlorothalonil + flutolanil, and tebuconazole fungicide treatments. The vertical line represents the chlorothalonil standard. Means are not significantly different if the magnitude of the difference is not greater than the least significant difference (LSD) value according to Fisher's protected LSD $(P=0.05)$. tions originated from inoculum from adjacent peanut fields. The three fungicide programs provided similar levels of leaf spot control across the different irrigation timings. Trends similar to those observed in the leaflet assay were found for leaf spot, and results from the two assays from the final sampling date were correlated for all canopy layers $\left(0.19 \leq R^{2} \leq 0.32 ; P=0.0001\right)$.

Negative correlations were found between the percent pod colonization by $S$. rolfsii and the size of lesions on leaflets from the upper canopy for the 110-DAP sampling date $\left(R^{2}=-0.33 ; P=\right.$ $0.0001)$ and the number of leaf spot lesions per leaf $\left(R^{2}=-0.21 ; P\right.$ $=0.0001)$. Later irrigation timings resulted in increased pod colonization, and the percent colonization for azoxystrobin, tebuconazole, and flutolanil plus chlorothalonil all increased according to quadratic functions; however, lesion suppression for the
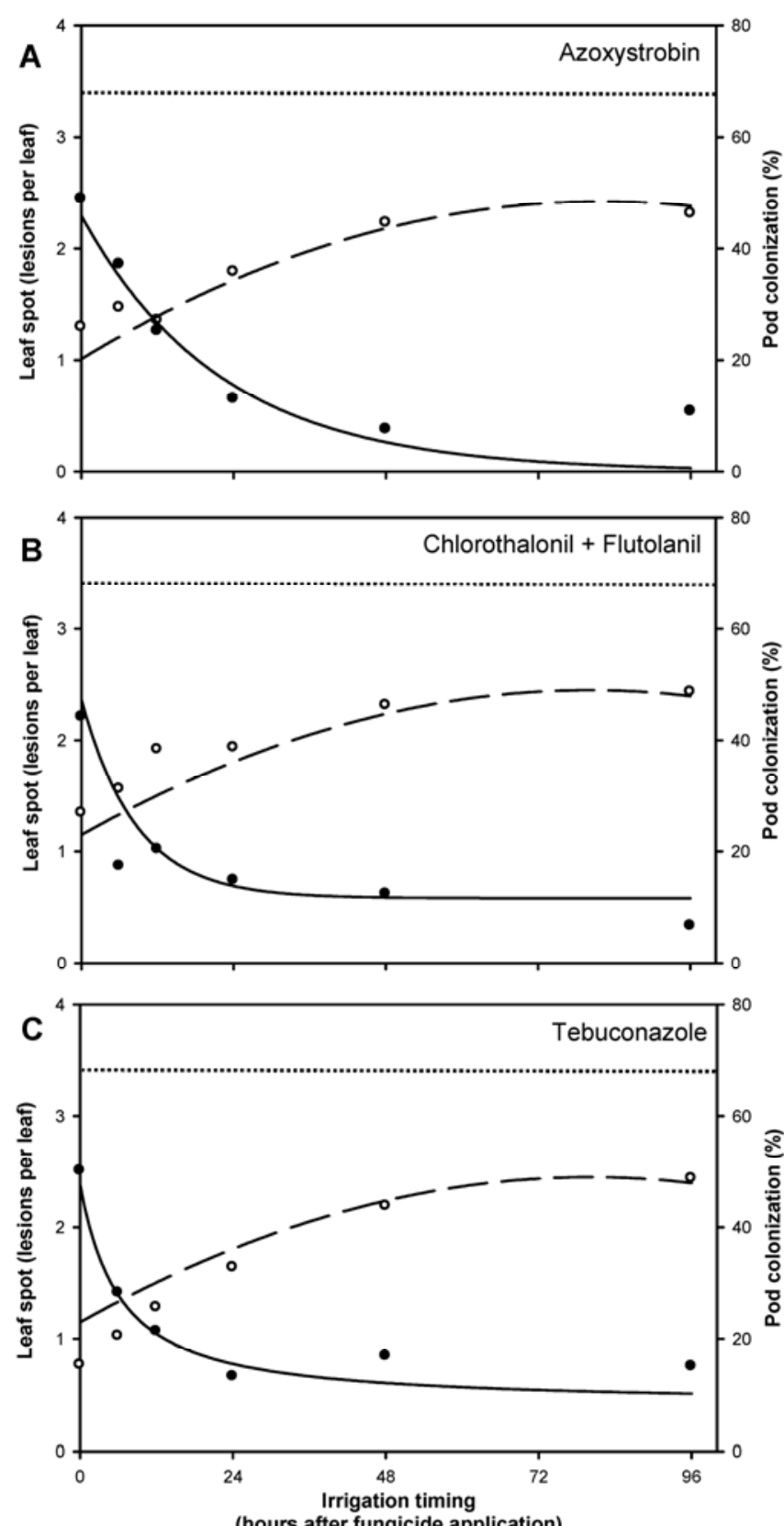

Fig. 2. Effect of irrigation timing on leaf spot and stem rot efficacy in peanut. Points represent the observed means; curved lines represent predicted values. Solid lines represent the number of leaf spot lesions per leaf; whereas the dashed lines represent percent pod colonization by Sclerotium rolfsii for $\mathbf{A}$, azoxystrobin; $\mathbf{B}$, chlorothalonil + flutolanil; and $\mathbf{C}$, tebuconazole. The horizontal dotted line represents the colonization of pods by $S$. rolfsii from pods obtained from plants treated with chlorothalonil alone. 
earlier irrigation timings was greatest for tebuconazole followed by flutolanil plus chlorothalonil and azoxystrobin, respectively. The rate of colonization increased for tebuconazole after $24 \mathrm{~h}$, whereas the rate of pod colonization for azoxystrobin and flutolanil plus chlorothalonil was at a more consistent rate.

The different physiochemical properties of these compounds, such as affinity to the leaf surface, permeability, and the rate of uptake, could have attributed to this trend. Araki (1) reported that flutolanil is readily absorbed by rice (Oryza sativa L.) roots, and translocated acropetally; however, the systemic activity of flutolanil in peanut foliage is poorly understood. Information regarding the systemicity of EBI and QoI fungicides is well documented, at least in some crops. Previous reports have found that EBI fungicides, such as propiconazole (30), difenoconazole (22), simeconazole (46), and tebuconazole (34) quickly penetrate leaves after application. However, foliar uptake of azoxystrobin is more of a gradual process, with $<5 \%$ of the applied material being absorbed within $24 \mathrm{~h}$ of application (5). Persistence of these fungicides on the leaf surface may also explain the differences in the percent pod colonization for the nonirrigated controls. Pod colonization was significantly reduced for the nonirrigated controls for azoxystrobin, flutolanil plus chlorothalonil, and tebuconazole when compared with the chlorothalonil standard. Significant differences among the azoxystrobin, flutolanil plus chlorothalonil, and tebuconazole nonirrigated controls were also observed. Pod colonization was greatest for tebuconazole and lowest for azoxystrobin, whereas flutolanil plus chlorothalonil provided an intermediate level of suppression. Because tebuconazole is rapidly taken up by the leaf, less of the initial deposits may have been available for redistribution at the later irrigation timings, whereas azoxystrobin remains on the leaf surface for a longer period. This trait would be an advantage for azoxystrobin when peanut crops are planted in nonirrigated fields. Traditionally, azoxystrobin has been used more extensively in irrigated fields due to somewhat higher cost and superior activity on Rhizoctonia limb rot, caused by Rhizoctonia solani Kühn AG4 (31), which is primarily a disease of irrigated peanut (4). Results from these studies can also be used to aid in the decision to retreat fields in the event that rainfall occurs too soon after fungicides are applied.

Another factor to consider when interpreting the results of this study is the effect of rainfall following fungicide application. To exclude irrigation and rainfall in controls and treatments not scheduled to receive irrigation, microplots were covered with plywood sheets. However, following the 96-h irrigation timing, all microplots remained uncovered until the next application of fungicides. During this time, all microplots were subjected to natural environmental conditions. Rainfall amounts of 14.0, 6.4, and $6.6 \mathrm{~cm}$ in 2003, 2004, and 2005, respectively (29), undoubtedly redistributed some fungicide residues which remained on the leaf surface longer than 96 $\mathrm{h}$ after application (28). The effects of this are not fully understood, but this response would have been uniform across all plots.

In Georgia, several management strategies are used to minimize losses caused by soilborne pathogens. Recommendations include crop rotation, the use of moderately resistant cultivars, and timely application of foliar-applied fungicide, with subsequent irrigation used to redistribute them $(32,33)$. However, if irrigation is administered or rainfall experienced too soon, the level of leaf spot control could be reduced. Currently, producers are advised to wait a minimum of $12 \mathrm{~h}$ before administering irrigation to obtain adequate leaf spot control (33). Results from this study indicate that longer drying times may be required to fully maximize leaf spot control, and that this delay could negatively impact the control of stem rot on pods. If fungicides are solely being used to control stem rot, irrigation should be applied as quickly as possible to optimize disease suppression. Further studies to verify the impact of early irrigation on overall disease control and yield are required.

\section{Literature Cited}

1. Araki, F. 1985. Moncut (Flutolanil), a new systemic fungicide. Japan Pesticide Info. No. 47:23-25.
2. Aycock, R. A. 1966. Stem rot and other diseases caused by Sclerotium rolfsii. N. C. Agric. Exp. Stn. Tech. Bull. 174.

3. Backman, P. A., and Crawford, M. A. 1985. Effects of triazole fungicides on soilborne diseases of peanuts. (Abstr.) Proc. Am. Peanut Res. Ed. Soc. $17: 42$.

4. Barnes, J. S., Csinos, A. S., and Hook, J. E. 1990. Effects of fungicides, cultivars, irrigation, and environment on Rhizoctonia limb rot of peanut. Plant Dis. 74:671- 676.

5. Bartlett, D. W., Clough, J. M., Godwin, J. R., Hall, A. A., Hamer, M., and Parr- Bobrzanski, B. 2002. Review: the strobilurin fungicides. Pest. Manage. Sci. 58:649-662.

6. Beasley, J., Baldwin, J., and Padgett, B. 1997. Peanut Production Field Guide. Univ. Ga. Coop. Ext. Ser. Bull. 1146.

7. Brenneman, T. B., and Culbreath, A. K. 1994. Utilizing a sterol demethylation inhibiting fungicide in an advisory program to manage foliar and soilborne pathogens of peanut. Plant Dis. 78:866-872.

8. Brenneman, T. B., and Murphy, A. P. 1991. Activity of tebuconazole on Cercosporidium personatum, a foliar pathogen of peanut. Plant Dis. 75:699703.

9. Brenneman, T. B., Murphy, A. P., and Csinos, A. S. 1991. Activity of tebuconazole on Sclerotium rolfsii and Rhizoctonia solani, two soilborne pathogens of peanut. Plant Dis. 75:744-747.

10. Brenneman, T. B., Phipps, P. M., and Stipes, R. J. 1988. A rapid method for evaluating genotype resistance, fungicide activity, and isolate pathogenicity of Sclerotinia minor in peanut. Peanut Sci. 15:104-107.

11. Brenneman, T. B., Sumner, H. R., and Harrison, G. W. 1990. Deposition and retention of chlorothalonil applied to peanut foliage: effects of application methods, fungicide formulations and oil additives. Peanut Sci. 17:8084.

12. Bruhn, J. A., and Fry, W. E. 1982. A mathematical of the spatial and temporal dynamics of chlorothalonil residues on potato foliage. Phytopathology 72:1306-1312.

13. Cooke, B. K., Hislop, E. C., Jordan, W. L., Western, N. M., and Herrington, P. J. 1989. Redistribution of foliar surface deposits of prochloraz by simulated rainfall and the control of eyespot disease of winter wheat. Crop Prot. 8:373-379.

14. Csinos, A. S. 1984. Evaluation of the insecticide chlorpyrifos for activity against southern stem rot on peanuts. Peanut Sci. 11:98-102.

15. Csinos, A. S. 1986. Aiming the magic bullet for Sclerotium rolfsii. Proc. Am. Peanut Res. Educ. Soc. 18:58.

16. Csinos, A. S. 1987. Control of southern stem rot and Rhizoctonia limb rot of peanut with flutolanil. Peanut Sci. 14:55-58.

17. Csinos, A. S. 1989. Targeting fungicides for control of southern stem rot on peanut. Plant Dis. 73:723-726.

18. Csinos, A. S., and Kvein, C. S. 1988. Deposition of sprays on the soil for soil-borne targets of peanut. (Abstr.) Proc. Am. Peanut Res. Educ. Soc. 20:34.

19. Csinos, A. S., Kvien C. S., and Littrell, R. H. 1987. Activity of diniconazole on foliar and soilborne diseases of peanut. Appl. Agric. Res. 2:111-116.

20. Culbreath, A. K., Brenneman, T. B., Bondari, K., Reynolds, K. L., and McLean, H. S. 1995. Late leaf spot, southern stem rot, and peanut yield responses to rates of cyproconazole and chlorothalonil applied alone and in combination. Plant Dis. 79:1121-1125.

21. Culbreath, A. K., Minton, N. A., Brenneman, T. B., and Mullinix, B. G. 1992. Response of Florunner and Southern Runner peanut cultivars to chemical treatments for management of late leaf spot, southern stem rot, and nematodes. Plant Dis. 76:1199-1203.

22. Dahmen, H., and Staub, T. 1992. Biological characterization of uptake, translocation, and dissipation of difenoconazole (CGA 169374) in wheat, peanut, and tomato plants. Plant Dis. 76:523-526.

23. Draper, N. R., and Smith, H. 1981. Applied Regression Analysis, 2nd ed. Wiley, New York.

24. Grichar, W. J., Besler, B. A., and Jaks, A. J. 2000. Use of azoxystrobin for disease control on Texas peanut. Peanut Sci. 27:83-87.

25. Hagan, A. K., Rivas-Divila, M. E., Bowen, K. L., and Wells, L. 2004. Comparison of fungicide programs for the control of early leaf spot and southern stem rot on selected peanut cultivars. Peanut Sci. 31:22-27.

26. Hagan, A. K., Weeks, J. R., and Reed, R. B. 1986. Southern stem rot suppression on peanut with the insecticide chlorpyrifos. Peanut Sci. 13:3637.

27. Hamm, P. B., and Clough, G. H. 1999. Comparison of application methods on deposition and redistribution of chlorothalonil in a potato canopy and potential for control of late blight. Plant Dis. 83:441-444.

28. Hislop, E. C., and Cox, T. W. 1970. Local redistribution of fungicides on leaves by water. Ann. Appl. Biol. 66:89-101.

29. Hoogenboom, G., Coker, D. D., Edenfield, J. M., Evans, D. M., and Fang, C. 2003. The Georgia Automated Environmental Monitoring Network: 10 years of weather information for water resources management. Pages 896900 in: Proc. 2003 Ga. Water Resour. Conf. K. J. Hatcher, ed. Institute of Ecology, University of Georgia, Athens.

30. Kelly, R. 1980. Mode of action, postinfection control characteristics and systemic properties of selected triazole and imidazole fungicides for use against Venturia inaequalis. Ph.D. dissertation, Michigan State University, East Lansing. 
31. Kemerait, R. C., Jr. 2004. Peanut. Page 10 in: 2003 Georgia Plant Disease Loss Estimates. J. L. Williams-Woodward, ed. Univ. Ga. Coop. Ext. Ser. Athens.

32. Kemerait, R. C., Brenneman, T. B., and Culbreath, A. K. 2005. Peanut disease control. Pages 122-123 in: Georgia Pest Management Handbook, Commercial Edition. P. Guillebeau, ed. Univ. Ga. Coop. Ext. Ser. Athens

33. Kemerait, R. C., Brenneman, T. B., and Culbreath, A. K. 2006. 2006 Peanut Disease Update. Pages 22-35 in: Peanut Update. E. Prostko, ed. Univ. Ga. Coop. Ext. Ser. CSS-06-0112.

34. Kuck, K. H., and Thielert, W. 1987. On the systemic properties of HWG 1608 , the active ingredient of the fungicides Folicur and Raxil. Pflanzenschutz Nachr. Bayer (Ger. Ed.) 40:133-152.

35. Kudsk, E., Mathiassen, S. K., and Kirknel, E. 1991. Influence of formulations and adjuvants on the rainfastness of maneb and mancozeb on pea and potato. Pestic. Sci. 33:57-71.

36. Melouk, H. A., and Backman, P. A. 1995. Management of soilborne fungal pathogens. Pages 75-82: in Peanut Health Management. H. A. Melouk and F. M. Shokes, eds. American Phytopathological Society, St. Paul, MN.

37. Neely, D. 1970. Persistence of foliar protective fungicides. Phytopathology 60:1583-1586

38. Neely, D. 1971. Deposition and tenacity of foliage protectant fungicides. Plant Dis. Rep. 55:898-902.

39. Punja, Z. K. 1985. The biology, ecology, and control of Sclerotium rolfsii. Annu. Rev. Phytopathol. 23:97-127.

40. Rideout, S. L. 2002. Influence of environment and host growth for im- proved fungicide applications for control of southern stem rot of peanut. Ph.D. dissertation, University of Georgia, Athens.

41. Skoss, J. D. 1955. Structure and composition of plant cuticle in relation to environmental factors and permeability. Bot. Gaz. 117:55-72

42. Snedecor, G. W., and Cochran, W. G. 1967. Statistical Methods, 6th ed. Iowa State University, Ames.

43. Smith, D. H., and Littrell, R. H. 1980. Management of peanut foliar diseases. Plant Dis. 64:356-361.

44. Smith, F. D., and MacHardy, W. E. 1984. The retention and redistribution of captan on apple foliage. Phytopathology 74:894-899.

45. Taylor, S. 1996. Effect of time interval prior to rainfall on the efficacy of tebuconazole against Cercosporidium personatum. (Abstr.) Proc. Am. Peanut Res. Educ. Soc. 28:51.

46. Tsuda, M., Itoh, H., and Kato, S. 2004. Evaluation of the systemic activity of simeconazole in comparison with that of other DMI fungicides. Pest. Manage. Sci. 60:875-880.

47. VanBruggen, A. H. C., Osmeloski, J. F., and Jacobson, J. S. 1986. Effects of simulated acidic rain on wash-off of fungicides and control of late blight on potato leaves. Phytopathology 76:800-804.

48. Woodward, J. E., and Brenneman, T. B. 2008. Development of an inoculation method for quantifying fungicide residues on peanut foliage. Peanut Sci. 35:25-31

49. Zhu, H., Dorner, J. W., Rowland, D. L., Derksen, R. C., and Ozkan, H. E. 2003. Spray penetration into peanut canopies with hydraulic nozzle tips. Biosyst. Eng. 87:275-283. 